\title{
Determinants of SMEs Performance of the Gem and Jewelry Industry in Thailand: A Pilot Study
}

\author{
Nifaosan Raden Ahmad ${ }^{1}$, Mohd Noor Mohd Shariff ${ }^{1} \&$ Muhammad Haroon Hafeez ${ }^{2}$ \\ ${ }^{1}$ School of Business Management, College of Business, Universiti Utara Malaysia, Kedah Darul Aman, Malaysia \\ ${ }^{2}$ Institute of Management Sciences (Business Administration), Bahauddin Zakariya University, Multan, Pakistan \\ Correspondence: Nifaosan Raden Ahmad, School of Business Management, College of Business, Universiti Utara \\ Malaysia, 06010 UUM Sintok, Kedah Darul Aman., Malaysia. Tel: 60-16-406-1051.
}

Received: September 7, 2017

Accepted: September 22, 2017

Online Published: September 28, 2017

doi:10.20849/ajsss.v2i3.173

URL: https://doi.org/10.20849/ajsss.v2i3.173

\begin{abstract}
The main purpose of this pilot study is to examine and quantitatively explore a small sample of data on the determinants of strategic orientations and access to finance towards SMEs performance of the Gem and Jewelry Industry in Thailand. The proposed model consists of four elements that are used as a determinant of SMEs performance. A personally administered questionnaire approach was employed to collecting data from firms located in the Jewelry Trade Center, one of the most important premises for trading diamonds, gems, and jewelry in Thailand. The validity and reliability of the instruments were evaluated through panel of experts and data was analyzed using the SmartPLS 2.0.M3 software. The questionnaire revision was made based on the feedback of experts and the results confirmed that the remained items and constructs have good internal consistency reliability. A pilot test shows that there is no issue of validity and reliability of the instrument. The results of pilot test also will be beneficial to the further actual research on a larger scale by helping to avoid the potential research problems.
\end{abstract}

Keywords: SMEs, gem \& jewelry, pilot study, SmartPLS, Thailand

\section{Introduction}

Small and medium enterprises (SMEs) have been recognized as the backbone of the economy in both developed and developing countries. Thailand is a developing country, located in South-East Asia region, which SMEs play a vital role in the Thai economy by contributing significant contributions to the national gross domestic product (GDP), job opportunities, and poverty alleviation (Pathak \& Ahmad, 2016). SMEs in Thailand are considered as the key factor for economic development and employment in the country. According to the Office of SMEs Promotion (OSMEP), the GDP value of Thai SMEs in 2015 was $41.1 \%$ compared to large enterprises and others that contributed to $49.8 \%$ of the total GDP in the country, whereas $80.44 \%$ of overall employment had been created by SMEs (OSMEP, 2016). The contribution of SMEs to GDP among ASEAN countries ranges from $23 \%$ to $58 \%$ (ERIA, 2014), suggesting the contribution of Thai SMEs to GDP is still low and need to improve performance. The Gem and Jewelry Industry is the most important industry to the local economy since gem and jewelry are the main export productions of Thailand.

According to the Gem and Jewelry Institute of Thailand (GIT) trade review in 2016, the export value of gem and jewelry products declined from the previous year by $3.03 \%$ due to the negative factors from volatile global economy and lower demand from major trading partners (GIT, 2016). Notwithstanding this, the regional competitors such as China and India are the key competitors in gaining a greater share of the global jewelry market. In order to against the entering of rivals and secure the leading position in the marketplace, Thai SMEs have to be able to adapt towards changes in the business world by creating competitive advantage for a better performance. So far, Thai SMEs have encountered problems and barriers in improving their performance. Nupap et al. (2012) categorized the problems into four perspectives; product, process, information technology, and people perspectives. Most of Thai SMEs have had challenges with a variety of problematic aspects including; managerial skills and knowledge (Chumkate, 2015), a lack of access to financial resources, marketing skills, and entrepreneurial skills (Pholphirul \& Bhatiasevi, 2012), and also a lack of using advanced technology in production or manufacturing (Rojsurakitti, 2015). 
Strategic orientations that nowadays are widely adopted by firms since they create behaviors and influence activities that lead to superior performance (Sen, 2014). Herath and Mahmood (2013) indicate that strategic orientations have been considered as valuable and unique organizational resources for generating the competitive advantage in SMEs which can improve the success of SMEs. In the existing literature, most often mentioned are three types of strategic orientation including; entrepreneurial orientation (EO), market orientation (MO), and learning orientation (LO) in the studies of SMEs (Ejdys, 2014). There have been a lot of studies reveal that strategic orientations have an impact on business performance (Laukkanen et al., 2013; Nakola et al., 2015; Ali et al., 2016), whereas some studies found no effect of strategic orientations on firm performance (Obeidat, 2016). According to Baron and Kenny (1986), the issue of moderator should be considered in the inconclusive direction of the relation between predictor variable and dependent variable.

Several studies reveal that EO has a direct effect on firm performance (Shehu \& Mahmood, 2014; Hakala, 2013), while a study found the negative effect of EO on firm performance (Lechner \& Gudmundsson, 2014). Likewise, the studies of MO towards firm performance indicate the positive relationship (Lee et al., 2015; Qu \& Zhang, 2015), whereas Arshad et al. (2012) demonstrate MO had a negative impact on firm performance. Similarly, the studies proved positive relationship between LO and firm performance (Frank et al., 2012; Martinette et al., 2014), while Long (2013) found that LO has no significant effect on firm performance. Additionally, access to finance has a strong positive impact on firm performance (Nwosu \& Orji, 2016). Nonetheless, the combined effects of all these orientations (EO, MO, LO) towards firm performance at the level of SMEs attract limited research attention to date (Herath \& Mahmood, 2014; Deutscher et al., 2016). In view of the above, this paper intends to use access to finance as a moderator in the relationship between EO, MO, LO and SMEs performance.

A pilot test was conducted in this study due to the two main reasons, firstly, to evaluate the validity and reliability of the instrument. Secondly, to review the situation which will enable the researcher to anticipate and adjust potential problems when starting on the actual research. According to Johanson and Brooks (2010), the fundamental purpose of conducting a pilot study is to evaluate the feasibility of a small study for helping to design a further confirmatory study. It serves as an earlier-phase developmental function in improving the probability of success on a larger scale (Leon et al., 2011). Hazzi and Maldaon (2015) imply further that to avoid the potential research problems, a pilot study should address the most important methodological issues including; back-translation, missing data, normality, and reliability. In addition, a pilot study is not conducted for hypothesis testing and still poorly reported (Arain et al., 2010). However, to ensure the validity and reliability of the measures, this paper presents the result of pilot test about determinants of SMEs performance in the gem and jewelry industry of Thailand.

\section{Literature Review}

\subsection{Definitions of SMEs in Thailand}

The term of SMEs stands for "small and medium enterprises" that there is currently no consensus definition of the term. The definitions of SMEs can be defined by different approaches, vary regionally and organizationally. The existence of definitions can be divided into three flanks provided by international institutions, national laws, and industry using quantitative approach and qualitative approach, for instance, the European Commission uses three quantitative criteria for defining SMEs; number of employees, annual turnover, and annual balance sheet, whereas the World Bank uses number of employees, total assets in U.S. dollars, and annual sales in U.S. dollar (Berisha \& Pula, 2015). The quantitative approach is commonly used in defining SMEs since these criteria allow distinguishing the obvious categories of SMEs among small and medium-sized firms thus the European Commission identifies a SME as an enterprise with fewer 250 employees, and that has a net turnover fewer than 50 million Euros, and/or a total balance sheet fewer than 43 million Euros (Buculescu, 2013).

In Thailand, SMEs are generally defined based on the number of employees and fixed capital excluding land and properties as introduced by the Ministry of Industry on September 11, 2002 (OECD, 2016). A small enterprise is defined as a firm with fewer than 50 employees in production and service sectors, and less than 25 employees in wholesale sector. A medium enterprise is defined as an enterprise with employees fewer than 200 persons in production and service sectors, while employs employees not exceeding 50 persons in wholesale sector. Likewise, a small enterprise is defined as an enterprise with fixed capital not more than THB 50 million along three sectors; production, service and wholesale. A medium enterprise is defined as an enterprise with fixed capital of between THB 51 million to THB 200 million in production and service sectors, while THB 26 million to THB 50 million in wholesale sector (see Table 1). The definition of SMEs in Thailand is in line with the European Commission and World Bank in using the number of employees as a criterion to classify a SME. Thus, Thai SMEs are defined as enterprises with employees fewer than 200 persons, and with fixed capital, excluding lands and properties, not exceeding THB 200 million. 
Table 1. Definition of SMEs in Thailand

\begin{tabular}{lllll}
\hline Type & Small & \multicolumn{3}{l}{ Medium } \\
\cline { 2 - 5 } & Employees & Capital (THB million) & Employees & Capital (THB million) \\
\hline Production & Not more than 50 & Not more than 50 & $51-200$ & $51-200$ \\
Service & Not more than 50 & Not more than 50 & $51-200$ & $51-200$ \\
Wholesale & Not more than 25 & Not more than 50 & $26-50$ & $51-100$ \\
\hline
\end{tabular}

Note. Adopted from "Financing SMEs and Entrepreneur 2016: An OECD Scoreboard," by OECD, 2016. OECD Publishing, Paris. Copyright 2016 by OECD.

\subsection{Role of SMEs in Economy}

Thai SMEs are considered as the most critical drive of economic development in the Thailand's economy (Chanin et al., 2016). According to the office of SMEs promotion (OSMEP), it shows the report in 2014 that SMEs were $99.73 \%$ of the total number of enterprises in Thailand that contributed to $39.6 \%$ of the national GDP and employed $80.3 \%$ of overall employment (OSMEP, 2015). The report in 2014 also indicates that the service sector was the most significant contribution to the GDP accounting for $38.8 \%$, followed by the manufacturing sector at $27.7 \%$, and the wholesale, trade and maintenance sector at $13.9 \%$ respectively (OSMEP, 2015). Moreover, the role of SMEs operating in the service sector was the highest proportion of employment creation at $44.77 \%$ of all employment of SMEs, followed by the wholesale sector accounting for $31.57 \%$, and the manufacturing sector at $23.09 \%$ respectively (OSMEP, 2015). In addition, the total export value of SMEs in 2014 was THB $1,917,817.12$ million or $26.25 \%$ of the total value of exports, increased by $8.26 \%$ from 2013 , that the export value of gems and ornaments was considered as one of the highest proportions of exports for SMEs in Thailand amounted to $13.64 \%$ (OSMEP, 2015).

\section{$2.3 \mathrm{Gem}$ and Jewelry Industry}

According to the board of investment of Thailand (BOI), the role of SMEs operating in gem and jewelry industry is relatively more important in the Thailand's economy (BOI, 2014). The SMEs of the industry employed 865,656 people that were divided into three industry segments; upstream, midstream, and downstream (Thammaruaksa et al., 2010). In 2016, the export value of gem and jewelry products reached USD 14,246.60 million that was the third most important export product accounted for $6.62 \%$ of the country's total export value (GIT, 2016), and their contribution was around 3.5\% of the country's GDP (Note 1). The Thai gem and jewelry industry can be categorized into three main groups; diamond industry, colored stone industry, and jewelry industry (GIT, 2017). The colored stone products from Thailand has been widely recognized for a long time in the global market as a world-class colored stones, particularly the polished precious stones such as ruby and blue sapphire. The high-quality artisanship who possess exceptional skills in polishing colored stones, cutting diamonds, and jewelry making enable Thailand to become one of the top exporters of gem and jewelry products in international markets (BOI, 2014). Consequently, Thailand is the largest exporter of silver jewelry in the world (BOI, 2011).

\subsection{Challenges of SMEs in Thailand}

Currently, the performance of SMEs in Thailand is below expectations, particularly the SMEs in gem and jewelry industry. The export value of gem and jewelry products, excluding unwrought gold that was mainly used for investment purpose, has dropped drastically to $4.29 \%$ over the last three years (GIT, 2014; GIT, 2015; GIT, 2016). It is argued that the contribution of SMEs in gem and jewelry industry to the national gross export value is poor for numerous reasons. These include lack of effective financial resources to run the business, lack of research and development; and high market competition during the global economic recession due to the new entrants such as China, Singapore, Malaysia, and India (Kritchanchai \& Somboonwiwat, 2011; Nithisathian et al., 2012). Thus, in order to survive, Thai SMEs need to create a competitive advantage for maintaining their leading status in the global gem and jewelry industry. Hussain et al. (2013) imply that strategic orientations can provide firms with a competitive advantage to achieve superior performance which the most commonly adopted strategic orientations as determinants for firm performance are entrepreneurial orientation, market orientation, and learning orientation.

\subsection{Entrepreneurial Orientation}

The existing literatures have argued that entrepreneurial orientation (EO) plays an important role in explaining 
the performance of a firm (Doorn et al. 2015). The concept of EO was originally mentioned by Miller (1983), later modified by Covin and Slavin (1991), and further described by Lumpkin and Dess (1996) respectively. EO refers to the strategic process that a firm identifies new opportunities and implements entrepreneurial actions in order to generate a sustainable competitive advantage (Ruiz-Ortega et al., 2013). At first, the concept of EO identified by Miller (1983) and Covin and Slavin (1991) consists of three key dimensions, namely innovativeness, risk-taking, and proactiveness, and a five dimensional EO construct was suggested later by Lumpkin and Dess (1996) which additionally includes autonomy and competitive aggressiveness. Literatures confirmed that these three dimensions are the most commonly used in EO research instead of five dimensions (Soininen et al., 2013; Kropp et al., 2008). Innovativeness refers to the introducing new products, services and technological processes in an organization (Franco \& Haase, 2013). Risk-taking involves the willingness to commit important resources to opportunities that have a chance of success as well as failure (Altinay \& Wang, 2011). Proactiveness entails a forward-looking view that described by the introducing new products and services ahead of the competition and detecting future demand (Martin \& Javalgi, 2015). Moreover, several studies have confirmed that $\mathrm{EO}$ is one of the significant resources does positively influence firm performance (Eggers et al., 2013; Dada \& Watson, 2013; Zhang \& Zhang, 2012; Anderson \& Eshima, 2013; Kantur, 2016). In contrast, some studies found that there is no significant relationship between EO and firm performance (Chandrakumara et al., 2011; Affendy et al., 2015). Therefore, the the relationship between EO and firm performance seems to be inconclusive and requires further examination.

\subsection{Market Orientation}

According to Zebal and Goodwind (2012), market orientation (MO) generates superior performance for a firm. The notion of MO relates to the philosophy of marketing that can be defined into two main perspectives; cultural and behavioral perspectives (Hashim \& Bakar, 2011). Cultural perspective proposed by Narver and Slater (1990) views $\mathrm{MO}$ as organizational culture that comprises a set of beliefs generating the required behaviors of a firm to create superior value for customers. Naver and Slater (1990) imply that MO consists of three behavioral elements; customer orientation, competitor orientation, and inter-functional coordination. On the one hand, behavioral perspective proposed by Kohli and Jaworski (1990) views MO as the implementation of the marketing concept concerning a process of generating and disseminating market intelligence for future customer needs that consists of three main elements; the generation of market intelligence, intelligence dissemination, and responsiveness to market intelligence. In addition, MO by Narver and Slater (1990) outperforms MO by Kohli and Jaworski (1990) and also is understood equivalently across different populations in which researchers undertaking cross-country, cross-cultural, or cross-industry comparisons of MO should adopt Naver and Slater perspective (Rojas-Mendez \& Rod, 2013). Narver and Slater (1990) explain three behavioral elements for a definition; first, customer orientation refers to sufficient understanding of target buyers in order to create superior value for them continually; second, competitor orientation involves a firm understanding on the short-term strengths and weaknesses as well as the long-term capabilities and strategies of current and potential competitors; and third, inter-functional coordination refers the coordinated use of firm resources in creating superior value for target customers. Furthermore, several studies have reported different results on the influence of MO towards firm performance (Qu \& Zhang, 2015; Lee et al., 2015; Arshad et al., 2012; Roach, 2011; Apaydin, 2011). Consequently, further investigation on MO-performance relationship is needed.

\subsection{Learning Orientation}

Since the importance of learning in organization has been recognized in the 1960s, learning at the organizational level can be viewed from three perspectives; learning orientation (LO), learning organization, and organizational learning (Tan et al., 2014). LO is considered as a vital organizational value to enhance competitive advantage that refers to the activity of creating and using knowledge among its employees throughout an organization (Sinkula et al., 1997; Huang \& Li, 2017). Based on the existing literatures, LO is composed of three dimensions; commitment to learning, open-mindedness, and shared vision (Calisir et al., 2013). Commitment to learning involves the degree to which firms value behaviors that understand the cause and effect of their actions to regularly detect and correct errors in theory in use (Sinkula et al., 1997). Open-mindedness entails the notion of unlearning that firms are willing to critically question long-held routines, assumptions, and beliefs (Sinkula et al., 1997). Shared vision refers to deeply shared goals and missions among organizational members in order to pursuing a certain identity (Fang et al., 2014). Without a shared vision, organizational members are less likely to know what organizational expectations exist (Sinkula et al., 1997). Additionally, some studies have been conducted on the contribution of LO to firm performance and found that LO has a significant on performance (Martinette \& Obenchain-Leeson, 2012; Martinette et al., 2014; Frank et al., 2012). In contrast, several studies report that LO has a non-significant influence on performance (Wolff et al., 2015; Suliyanto \& Rahab, 2012; Ma 
et al., 2011). Thus, the relationship between $\mathrm{LO}$ and performance is unclear and requires further study.

\subsection{Access to Finance}

A broad range of recent studies suggest that firms should consider access to finance as one of the main challenges towards firm performance particularly in SMEs sector (Rupeika-Apoga, 2014). According to Kira and $\mathrm{He}$ (2012), access to finance enables firms to grasp investment opportunities in the way of helping them to acquire productive assets that can be used to increase productivity simultaneously reducing the unit cost of production for generating an increase in profit. Interestingly, access to finance is often considered as one of the most constraints of business environment that firms encounter (Ahmad \& Arif, 2015). In fact, there have been several studies on SMEs report that access to finance can improve their performance (Moreira, 2016; Kamunge et al., 2014; Adomako et al., 2016). Moreover, some studies have shown that access to finance moderates the relationship between a firm's resources and performance (Liu et al., 2014; Adomako \& Danso, 2014). Thus, access to finance can be recognized as a potential moderating variable that can influence on a firm's resources and performance. Nevertheless, there are limited studies have been examined the moderating role of access to finance on the relationship between strategic orientations (EO, MO, LO) as a firm's resources and performance of SMEs.

\section{Methodology}

A pilot study was conducted to examine the feasibility of a small study for helping design a further confirmatory study (Johanson \& Brooks, 2010). According to Hazzi and Maldaon (2015), a pilot study should address the most important methodological issues to avoid research problems including back-translation, missing data, normality, and reliability. In the study, back-translation was performed by two independent bilingual experts. A bilingual expert from the Language and Academic Services Centre, International College for Sustainability Studies, Srinakharinwirot University was the one who translated the measuring instrument from English to Thai whereas a bilingual expert from the Translation Services Unit, Faculty of Arts, Chulalongkorn University was the second one who blindly translated back from Thai to English. The comparison of two language versions was evaluated by an expert as a senior lecturer from the Foreign Languages Program, Faculty of Humanities and Social Sciences, Songkhla Rajabhat University. Kimberlin and Winterstein (2008) argue further that the reliability and validity of the measures are key indicators of the quality of a research instrument. Therefore, the content validity index (CVI) of the measures were assessed by three experts in the field of entrepreneurship and management areas, two experts from the Universiti Utara Malaysia and an expert from the Hatyai University. The CVI can be calculated for item-level (I-CVI) and scale-level (S-CVI) that both criteria values can be judged as having excellent content validity if the I-CVI is higher than 0.78 or the S-CVI is higher 0.90 (Polit et al., 2007).

The study used personally administered questionnaires to collecting data from firms located in the Jewelry Trade Center (JTC), one of the most important premises for trading diamonds, gems, and jewelry in Bangkok, Thailand. Since the response rate was very low for the mailed questionnaire survey approach, the personally administered questionnaire approach was adopted instead in the study after closing date. Out of the 85 questionnaires mailed to the respondents, 4 were returned within the period of four weeks in the month of December 2016, albeit the questionnaires were followed up by postcard reminders to improving mail survey response rates (Brennan, 1992). According to Sekaran and Bougie (2013), the personally administered questionnaires are best suited when the data are located in close proximity to one another. Then a copies of 36 questionnaires using closed-ended questions and five point-Likert scale were handed over to the owner-managers who operating their firms in the JTC building, and collected immediately after they were completed. Out of the 36 questionnaires personally distributed and 32 were returned, two of them had not been properly filled, and so only 30 were used for analysis that representing about 83 percent response rate. However, Johanson and Brooks (2010) suggest that 30 respondents from the population of interest is a reasonable minimum recommendation for a pilot study. The whole process of collecting data was completed within two days in the first week of January 2017. The SmartPLS 2.0.M3 software was used to test the reliability of the instrument.

\section{Result}

\subsection{Validity Test}

The content validity assessment forms including the key variables; entrepreneurial orientation, market orientation, learning orientation, access to finance, and SMEs performance were sent to panel of experts to give comments and measure the content validity index (CVI) using a 4-point scale, ranging from not relevant to highly relevant (Polit \& Beck, 2006). The assessment form is made up of five sections. Section 1: consists of a set of 14 items that seek to measure the level of entrepreneurial orientation as perceived by the respondents. 
Section 2: comprises of 15 items which attempt to measure the market orientation as perceived by the respondents. Section 3: is made up of a total of 12 items which are meant to assess the level of learning orientation perceived by the respondents. Section 4: contains five items that are targeted to evaluate the access to finance. And finally, section 5: consists of 17 items which attempt to measure the SMEs performance perceived by the respondents. The three experts consulted include professor, associate professor, and senior lecturer in the School of Business Management, Universiti Utara Malaysia and Hatyai University. A minimum of three experts should be used for content validity determination (Lynn, 1986). Based on the foregoing, a number of questions were re-worded in order to measure the construct appropriately and also to be understandable to the potential respondents. It was also observed that two items were recommended to be removed. After taking into the consideration of the observation by the experts, among the 63 items, two items with CVI score lower than 0.70 were eliminated, three items were modified according to the recommendation of panel members, and then the instrument contains 61 items after modification. Table 2 shows the calculation of I-CVI, S-CVI, and modified items in the instrument for 61 remaining items at the end.

Table 2. Content validity index

\begin{tabular}{|c|c|c|c|c|}
\hline Construct & Items of construct & $\begin{array}{l}\text { Number of giving } \\
\text { rating of } 3 \text { or } 4\end{array}$ & I-CVI & Interpretation \\
\hline \multirow{14}{*}{$\begin{array}{l}\text { Entrepreneurial } \\
\text { Orientation }\end{array}$} & EO-1 & 2 & 0.67 & Fair \\
\hline & EO-2 & 3 & 1.00 & Excellent \\
\hline & EO-3 & 3 & 1.00 & Excellent \\
\hline & EO-4 & 3 & 1.00 & Excellent \\
\hline & EO-5 & 3 & 1.00 & Excellent \\
\hline & EO-6 & 3 & 1.00 & Excellent \\
\hline & EO-7 & 3 & 1.00 & Excellent \\
\hline & EO-8 & 3 & 1.00 & Excellent \\
\hline & EO-9 & 3 & 1.00 & Excellent \\
\hline & EO-10 & 3 & 1.00 & Excellent \\
\hline & EO-11 & 3 & 1.00 & Excellent \\
\hline & EO-12 & 3 & 1.00 & Excellent \\
\hline & EO-13 & 3 & 1.00 & Excellent \\
\hline & EO-14 & 3 & 1.00 & Excellent \\
\hline \multirow[t]{14}{*}{ Market Orientation } & MO-15 & 3 & 1.00 & Excellent \\
\hline & MO-16 & 3 & 1.00 & Excellent \\
\hline & MO-17 & 3 & 1.00 & Excellent \\
\hline & MO-18 & 3 & 1.00 & Excellent \\
\hline & MO-19 & 3 & 1.00 & Excellent \\
\hline & MO-20 & 3 & 1.00 & Excellent \\
\hline & MO-21 & 2 & 0.67 & Fair \\
\hline & MO-22 & 3 & 1.00 & Excellent \\
\hline & MO-23 & 3 & 1.00 & Excellent \\
\hline & MO-24 & 3 & 1.00 & Excellent \\
\hline & MO-25 & 1 & 0.33 & Eliminated \\
\hline & MO-26 & 3 & 1.00 & Excellent \\
\hline & MO-27 & 3 & 1.00 & Excellent \\
\hline & MO-28 & 3 & 1.00 & Excellent \\
\hline
\end{tabular}




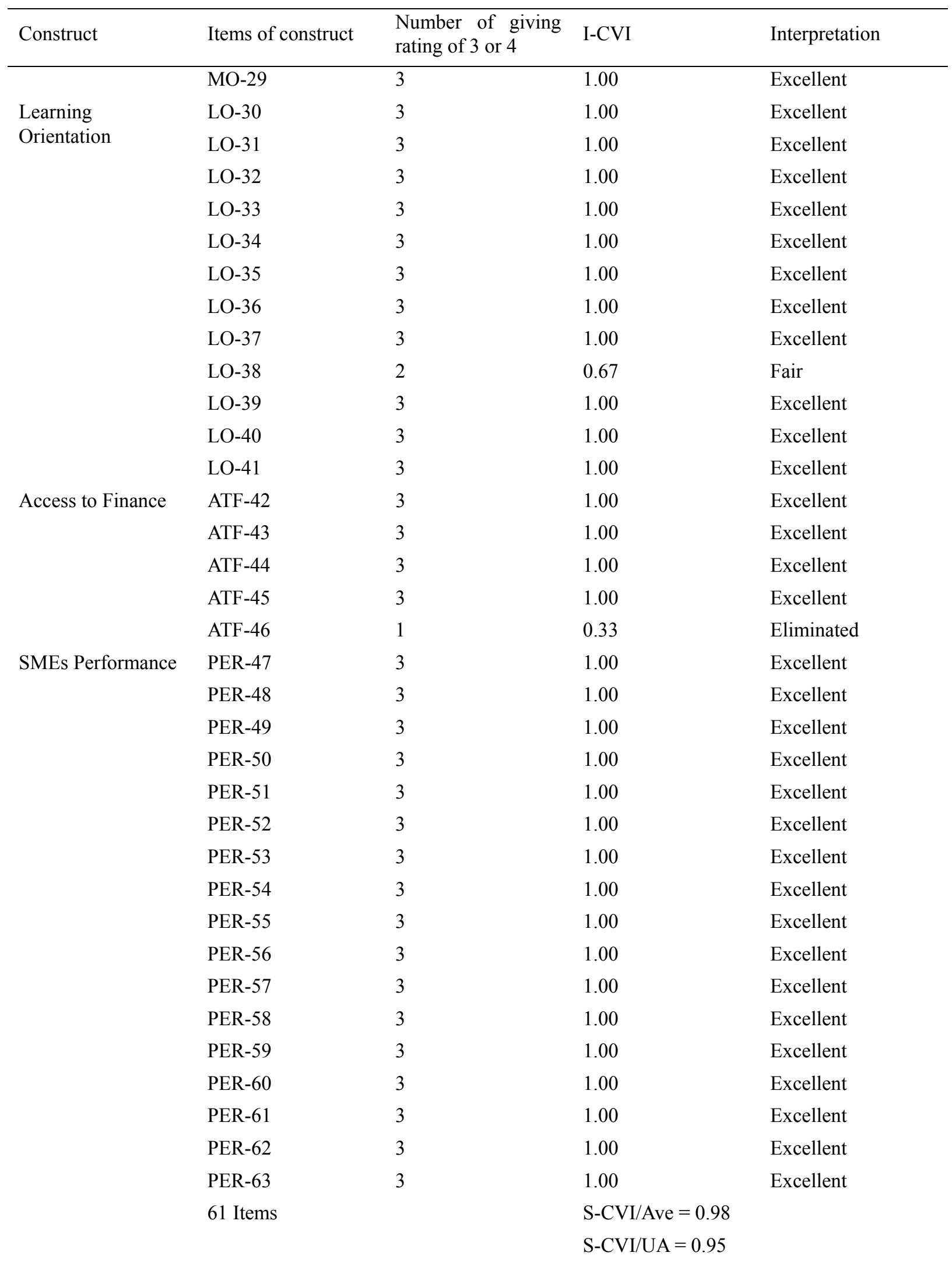

Note. I-CVI $=$ item-level content validity index, $\mathrm{S}-\mathrm{CVI} /$ Ave $=$ scale-level content validity index, averaging calculation method, S-CVI/UA = scale-level content validity index, universal agreement calculation method. 


\subsection{Reliability Test}

Partial least squares structural equation modeling (PLS-SEM) was adopted for this study since it works efficiently to estimate models with many constructs, typically more than five constructs (Sarstedt et al., 2014). The reliability was assessed using outer loadings, composite reliability (CR), and average variance extracted (AVE). According to Hair et al. (2011), rules of thumb for reflective measurement models evaluation are; indicator loading should be higher than 0.70, CR should be greater than 0.70, and AVE should be higher than 0.50. Hair et al. (2013) suggest further that in exploratory studies, indicator loadings of 0.40 are considered acceptable. However, this study used a cutoff value for loadings at 0.60 as significant (Hair et al. 2011). Table 3 and Figure 1 shows the loadings exceeded the recommended value of 0.60 after deleting some of the items. The CR values ranged from 0.74 to 0.95 which exceeded the recommended threshold value of 0.70 . The AVE was in the range of 0.55 to 0.67 which also exceeded the recommended value of 0.50 . Moreover, while criteria such as Cronbach's alpha and CR are the most common measure of internal consistency reliability, but Cronbach's alpha is limited by the assumption of tau-equivalence, then CR has been suggested as a replacement (Hair et al., 2012). Consequently, the results of the measurement model (see Table 3) can be concluded that all the five constructs; entrepreneurial orientation, market orientation, learning orientation, access to finance, and SMEs performance are all reliable measures. For discriminant validity, Table 4 indicates that the square root of each construct's AVE is greater than its correlation with another construct (Henseler et al., 2015).

Table 3. Result of the measurement model

\begin{tabular}{|c|c|c|c|c|c|}
\hline Model Construct & $\begin{array}{l}\text { Measurement } \\
\text { Item }\end{array}$ & Loading & CR & AVE & $\begin{array}{l}\text { Cronbach's } \\
\text { Alpha }\end{array}$ \\
\hline Entrepreneurial & EO-4 & 0.8471 & 0.8358 & 0.5618 & 0.7442 \\
\hline \multirow[t]{3}{*}{ Orientation } & EO-5 & 0.7559 & & & \\
\hline & EO-13 & 0.7179 & & & \\
\hline & EO-14 & 0.6656 & & & \\
\hline Market & MO-21 & 0.7642 & 0.8564 & 0.6670 & 0.7467 \\
\hline \multirow[t]{2}{*}{ Orientation } & MO-26 & 0.9112 & & & \\
\hline & MO-28 & 0.7659 & & & \\
\hline Learning & LO-29 & 0.7668 & 0.8776 & 0.5451 & 0.8382 \\
\hline \multirow[t]{5}{*}{ Orientation } & LO-30 & 0.7756 & & & \\
\hline & LO-34 & 0.7046 & & & \\
\hline & LO-37 & 0.6746 & & & \\
\hline & LO-38 & 0.7268 & & & \\
\hline & LO-40 & 0.7753 & & & \\
\hline Access to & ATF-41 & 0.7418 & 0.7365 & 0.5831 & 0.2857 \\
\hline Finance & ATF-44 & 0.7849 & & & \\
\hline SMEs & PER-47 & 0.6839 & 0.9521 & 0.6257 & 0.9448 \\
\hline \multirow[t]{11}{*}{ Performance } & PER-48 & 0.6718 & & & \\
\hline & PER-50 & 0.823 & & & \\
\hline & PER-51 & 0.7919 & & & \\
\hline & PER-52 & 0.9244 & & & \\
\hline & PER-53 & 0.787 & & & \\
\hline & PER-56 & 0.7342 & & & \\
\hline & PER-57 & 0.8982 & & & \\
\hline & PER-58 & 0.8037 & & & \\
\hline & PER-59 & 0.7126 & & & \\
\hline & PER-60 & 0.83 & & & \\
\hline & PER-61 & 0.7888 & & & \\
\hline
\end{tabular}

Note. $\mathrm{CR}=$ Composite Reliability, AVE $=$ Average Variance Extracted. 
Table 4. Discriminant validity of constructs

\begin{tabular}{llllll}
\hline Construct & 1 & 2 & 3 & 4 & 5 \\
\hline 1. Access to Finance & $\mathbf{0 . 7 6 3 6}$ & & & & \\
2. Entrepreneurial Orientation & 0.0739 & $\mathbf{0 . 7 4 9 5}$ & & & \\
3. Learning Orientation & 0.0037 & 0.3283 & $\mathbf{0 . 7 3 8 3}$ & & \\
4. Market Orientation & 0.3779 & 0.5249 & 0.6684 & $\mathbf{0 . 8 1 6 7}$ & \\
5. SMEs Performance & 0.3472 & 0.5330 & 0.4573 & 0.6760 & $\mathbf{0 . 7 9 1 0}$ \\
\hline
\end{tabular}

Note. Bold values are the square roots of average variance extracted (AVE).

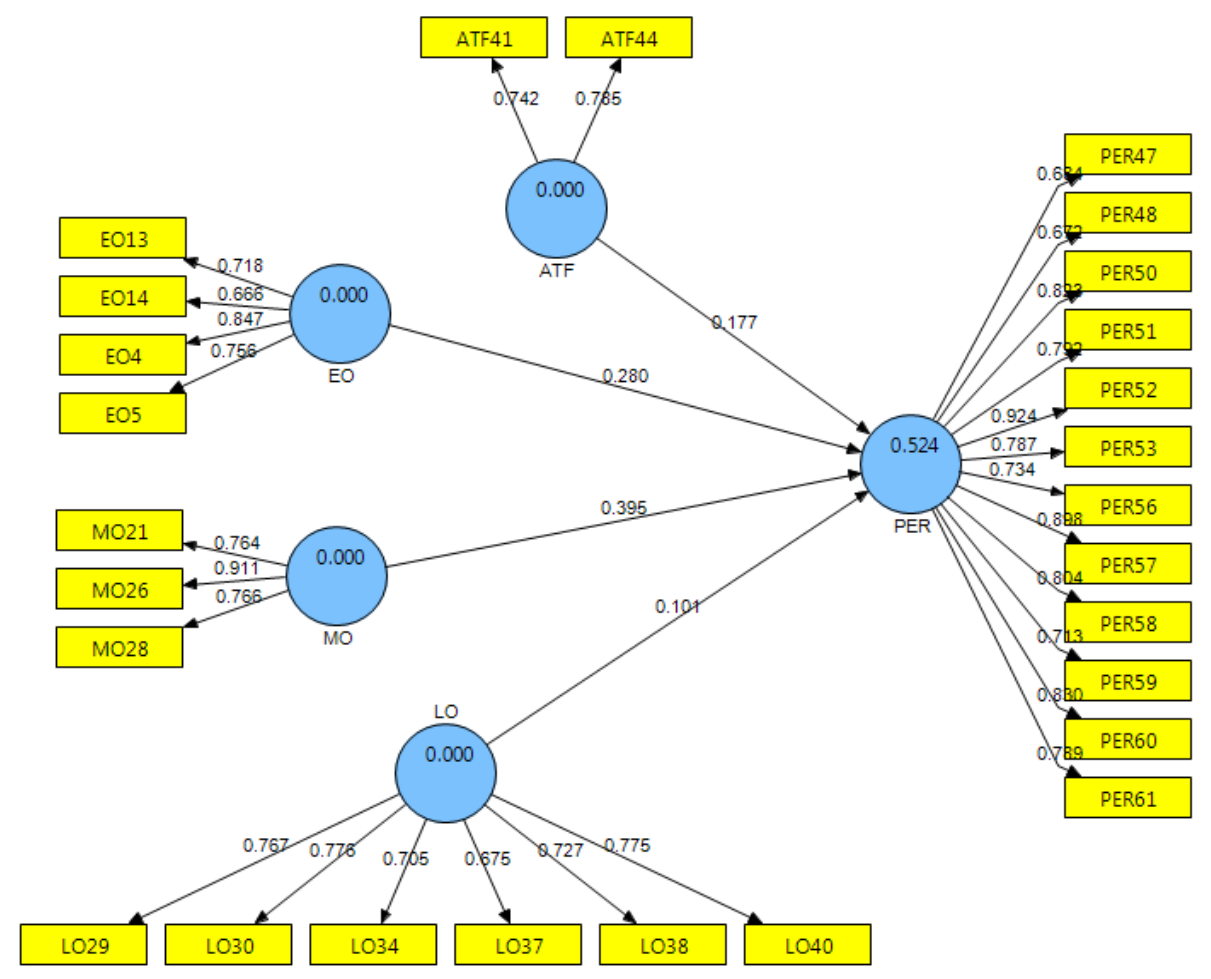

Figure 1. Structural model

\subsection{Demographic Profile of the Respondents}

The demographic profile of the respondents as depicted in Table 5 has been described in terms of seven different areas; gender, age, education, marital status, years of work experience, number of employees, and firm age. In term of gender, most of the respondents were female which was accounted by $56.7 \%$ and male respondents accounted for $43.3 \%$. Meanwhile, in term of age, $46.7 \%$ of the respondents aged between $41-50$ years, followed by $30.0 \%$ between $31-40$ years. Additionally, $16.7 \%$ of the respondents aged less than 30 years and only $6.7 \%$ above 50 years. Similarly, with respect to educational qualification, the respondents with less than a bachelor's degree were more than any other group which accounted for $46.7 \%$, while $40.0 \%$ were hold bachelor's degree, and $13.3 \%$ had a graduate degree. With regards to the marital status, the results show that the respondents' marital status of single and married sharing the same percent (43.3\%), and only $10 \%$ of respondents were widowed. Moreover, in term of years of work experience, $50.0 \%$ of respondents had more than ten years of work experience, while $20.0 \%$ had $4-6$ years and $16.7 \%$ had $2-4$ years of work experience. As a result, $93.3 \%$ of firms were small-sized and $6.7 \%$ were medium-sized. Finally, $23.3 \%$ of firms aged between $10-14$ years and over 20 years, followed by $16.7 \%$ of the total firms were between $7-9$ years and $15-19$ years, while $10.0 \%$ of the total firms were $1-3$ years and $4-6$ years. 
Table 5. Demographic profile of the respondents

\begin{tabular}{lll}
\hline Demographic Variable & Item & Percent \\
\hline Gender & Male & 43.3 \\
Age & Female & 56.7 \\
& Less than 30 & 16.7 \\
& $31-40$ & 30.0 \\
& $41-50$ & 46.7 \\
Education & More than 50 & 6.7 \\
& Less than Bachelor's Degree & 46.7 \\
Marital Status & Bachelor's Degree & 40.0 \\
& Graduate Degree & 13.3 \\
Yingle & 43.3 \\
Married of Work Experience & Widowed & 43.3 \\
& Less than 2 years & 10.0 \\
& $2-4$ years & 3.3 \\
Firm Age & $4-6$ years & 16.7 \\
& $6-10$ years & 20.0 \\
Number of Employees & More than 10 years & 10.0 \\
& Less than 5 employees & 50.0 \\
& $6-2$ employees & 33.3 \\
& $21-50$ employees & 46.7 \\
$51-200$ employees & 13.3 \\
& $1-3$ years & 6.7 \\
& $4-6$ years & 10.0 \\
& 10 years 14 years & 10.0 \\
& $15-19$ years & 16.7 \\
& Over 20 years & 23.3 \\
& & 23.3 \\
\hline
\end{tabular}

\section{Conclusion}

As noted earlier that the aim of this study is to conduct a pilot study to evaluate the validity and reliability of the instrument of current research in preparation for the large-scale study. The results of the pilot study reveal that this instrument enjoyed an appropriate level of content validity. Furthermore, findings of the pilot study illustrate that the composite reliability (CR) values of the instrument were above 0.74 after deletion of those items with loading lower 0.60 . Therefore, given the recognized benchmark of $\mathrm{CR}$, it can be concluded that the final instrument for 27 items remaining and five constructs have good internal consistency reliability.

\section{Acknowledgements}

We would like to thank our School of Business Management at Universiti Utara Malaysia (UUM) for all supports. We also would like to express special thanks to the UUM's staff and our colleagues for their time and advice in the preparation of this paper.

\section{References}

Adomako, S., \& Danso, A. (2014). Financial literacy and firm performance: The moderating role of financial capital availability and resource flexibility. International Journal of Management \& Organizational Studies, 
3(4), 1-15.

Adomako, S., Danso, A., \& Damoah, J. O. (2016). The moderating influence of financial literacy on the relationship between access to finance and firm growth in Ghana. Venture Capital, 18(1), 43-61.

Affendy, A. H., Asmat-Nizam, Abdul-Talib, \& Farid, M. S. (2015). Entrepreneurial orientation effects on market orientation and SMEs business performance - A SEM approach. Review of Integrative Business \& Economics Research, 4(3), 259-271.

Ahmad, S. Z., \& Arif, A. M. M. (2015). Strengthening access to finance for women-owned SMEs in developing countries. Equality, Diversity and Inclusion: An International Journal, 34(7), 634-639.

Ali, R., Leifu, G., \& Ramiz-ur-Rehman (2016). The impact of technology orientation and customer orientation on firm performance: Evidence form Chinese firms. International Journal of Management and Marketing Research, 9(1), 1-11.

Altinay, L., \& Wang, C. L. (2011). The influence of an entrepreneur's socio-cultural characteristics on the entrepreneurial orientation of small firms. Journal of Small Business and Enterprise Development, 18(4), 673-694.

Anderson, B. S., \& Eshima, Y. (2013). The influence of firm age and intangible resources on the relationship between entrepreneurial orientation and firm growth among Japanese SMEs. Journal of Business Venturing, 28(3), 413-429.

Apaydin, F. (2011). Moderating effect of adaptability on the relationship between two forms of market orientation and performance. Interdisciplinary Journal of Contemporary Research in Business, 3(2), 1364-1377.

Arain, M., Campbell, M. J., Cooper, C. L., \& Lancaster, G. A. (2010). What is a pilot or feasibility study? A review of current practice and editorial policy. BMC Medical Research Methodology, 10(67).

Arshad, R., Mansor, S. M., \& Othman, R. (2012). Market orientation, firm performance and the mediating effect of corporate social responsibility. The Journal of Applied Business Research, 28(5), 851-860.

Baron, R. M., \& Kenny, D. A. (1986). The moderator-mediator variable distinction in social psychological research: Conceptual, strategic, and statistical considerations. Journal of Personality and Social Psychology, 51(6), 1173-1182.

Berisha, G., \& Pula, J. S. (2015). Defining small and medium enterprises: a critical review. Academic Journal of Business, Administration, Law and Social Sciences, 1(1), 17-28.

BOI. (2011). Thai gems and jewelry industry. Thailand Investment Review, 21(7).

BOI. (2014). Gems \& Jewelry. Thailand Investment Review, 24(12).

Brennan, M. (1992). Techniques for improving mail survey response rates. Marketing Bulletin, 3, 24-37.

Buculescue, M. - M. (2013). Harmonization process in defining small and medium-sized enterprises: Arguments for a quantitative definition versus a qualitative one. Theoretical and Applied Economics, 9(586), 103-114.

Calisir, F., Gumussoy, C. A., \& Guzelsoy, E. (2013). Impacts of learning orientation on product innovation performance. The Learning Organization, 20(3), 176-194.

Chandrakumara, A., Zoysa, A., \& Manawaduge, A. (2011). Effects of the entrepreneurial and managerial orientations of owner-managers on company performance: An empirical test in Sri Lanka. International Journal of Management, 28(1), 139-199.

Chanin, O., Phooma, J., Somsuk, S., Temprasiri, P., \& Chanin, C. (2016). Guideline to Thailand-Malaysia border SME entrepreneurs' management capacity to create competitive advantage for Songkhla province, Thailand. International Journal of Innovation, Management and Technology, 7(4), 153-156.

Chumkate, J. (2015). Authentic evaluation and management approach of OTOP herbal product of SMEs entrepreneur in western region of Thailand. Journal of Advanced Management Science, 3(2), 123-127.

Covin, J. G., \& Slevin, D. P. (1991). A conceptual model of entrepreneurship as firm behavior. Entrepreneurship Theory and Practice, 16(1), 7-25.

Dada, O., \& Watson, A. (2013). Entrepreneurial orientation and the franchise system: Organizational antecedents and performance outcomes. European Journal of Marketing, 47(5/6), 790-812.

Deutscher, F., Zapkau, F. B., Schwens, C., Baum, M., \& Kabst, R. (2016). Strategic orientations and performance: 
A configurational perspective. Journal of Business Research, 69(2), 849-861.

Doorn, S. V., Heyden, M., Troster, C., \& Volberda, H. (2015). Entrepreneurial orientation and performance: Investigating local requirements for entrepreneurial decision-making. In Giovanni, G., \& William, O. (Eds.), Cognition and Strategy (Advances in Strategic Management, Volume 32) (pp. 211-239). Emerald Group Publishing Limited.

Eggers, F., Kraus, S., Hughes, M., Laraway, S., \& Snycerski, S. (2013). Implications of customer and entrepreneurial orientations for SME growth. Management Decision, 51(3). 524-546.

Ejdys, J. (2014). Strategic orientation of small and medium size enterprises. Economics and Management, 19(4), 346-358.

ERIA. (2014). ASEAN SME policy index 2014: Towards competitive and innovative ASEAN SMEs. Jakarka: Economic Research Institute for ASEAN and East Asia (ERIA).

Fang, S.-R., Chang, E., Ou, C.-C., \& Chou, C.-H. (2014). Internal market orientation, market capabilities and learning orientation. European Journal of Marketing, 48(1/2), 170-192.

Franco, M., \& Haase, H. (2013). Firm resources and entrepreneurial orientation as determinants for collaborative entrepreneurship. Management Decision, 51(3), 680-696.

Frank, H., Kessler, A., Mitterer, G., \& Weismeier-Sammer, D. (2012). Learning orientation of SMEs and its impact on firm performance. Journal of Marketing Development and Competitiveness, 6(3), 29-41.

GIT. (2014). Thailand's Gem and Jewelry Import-Export Performance 2014. Bangkok: The Gem and Jewelry Institute of Thailand (GIT).

GIT. (2015). Thailand's Gem and Jewelry Import-Export Performance 2015. Bangkok: The Gem and Jewelry Institute of Thailand (GIT).

GIT. (2016). Thailand's Gem and Jewelry Import-Export Performance 2016. Bangkok: The Gem and Jewelry Institute of Thailand (GIT).

GIT. (2017). Thai Gem and Jewelry Industry. Retrieved from Gem and Jewelry Information Center, The Gem and Jewelry Institute of Thailand (GIT). Retrieved from https://infocenter.git.or.th/

Hair, J. F., Ringle, C. M., \& Sarstedt, M. (2011). PLS-SEM: Indeed a silver bullet. Journal of Marketing Theory and Practice, 19(2), 139-151.

Hair, J. F., Ringle, C. M., \& Sarstedt, M. (2013). Partial least squares structural equation modeling: Rigorous applications, better result and higher acceptance. Long Range Planning, 46(1-2), 1-12.

Hair, J. F., Sarstedt, M., Ringle, C. M., \& Mena, J. A. (2012). An assessment of the use of partial least squares structural equation modeling in marketing research. Journal of the Academy of Marketing Science, 40(3), 414-433.

Hakala, H. (2013). Entrepreneurial and learning orientation: Effects on growth and profitability in the software sector. Baltic Journal of Management, 8(1), 102-118.

Hashim, F., \& Bakar, A. R. A. (2011). Antecedents and consequences of market orientation in non-profit organizations: Evidence from Malaysia. International Journal of Management and Marketing Research, 4(3), 95-105.

Hazzi, O. A., \& Maldaon, I. S. (2015). A pilot study: Vital methodological issues. Business: Theory and Practice /Verslas: Teorija ir Praktika, 16(1), 53-62.

Henseler, J., Ringle, C. M., \& Sarstedt, M. (2015). A new criterion for assessing discriminant validity in variance- based structural equation modeling. Journal of the Academy of Marketing Science, 43(1), 115-135.

Herath, H. M. A., \& Mahmood, R. (2013). Strategic orientation based research model of SME performance for developing countries. Review of Integrative Business \& Economics Research. 2(1), 430-440.

Herath, H. M. A., \& Mahmood, R. (2014). Strategic orientation and SME performance: Moderating effect of absorptive capacity of the firm. Asian Social Science, 10(13), 95-107.

Huang, F. - W., \& Li, Y. - H. (2017). The mediating role of ambidextrous capability in learning orientation and new product performance. Journal of Business \& Industrial Marketing, 32(5), 613-624.

Hussain, S. S., Azhar, S. M., \& Shahid, M. (2013). Strategic orientations and organizational types: A theoretical 
link, 2(3), 17-31.

Johanson, G. A., \& Brooks, G. P. (2010). Initial scale development: Sample size for pilot studies. Educational \& Psychological Measurement, 70(3), 394-400.

Kamunge, M. S., Njeru, A., \& Tirimba, O. I. (2014). Factors affecting the performance of small and micro enterprises in Limuru town market of Kiambu County, Kenya. International Journal of Scientific and Research Publications, 4(12).

Kantur, D. (2016). Strategic entrepreneurship: mediating the entrepreneurial orientation-performance link. Management Decision, 54(1), 24-43.

Kimberlin, C. L., \& Winterstein, A. G. (2008). Validity and reliability of measurement instruments used in research. American Journal of Health-System Pharmacy, 65(23), 2276-2284.

Kira, A. R., \& He, Z. (2012). The impact of firm characteristics in access to financing by small and medium-sized enterprises in Tanzania. International Journal of Business and Management, 7(24), 108-119.

Kohli, A. K., \& Jaworski, B. J. (1990). Market orientation: The construct, research propositions, and managerial implications. Journal of Marketing, 54, 1-18.

Kritchanchai, D., \& Somboonwiwat, T. (2011). Virtual network for diamond supply chain in Thailand. Operations and Supply Chain Management, 4(1), 55-64.

Kropp, F., Lindsay, N. J., \& Shoham, A. (2008). Entrepreneurial orientation and international entrepreneurial business venture startup. International Journal of Entrepreneurial Behaviour \& Research, 14(2), 102-117.

Laukkanen, T., Nagy, G., Hirvonen, S., Reijonen, H., \& Pasanen, M. (2013). The effect of strategic orientations on business performance in SMEs: A multigroup analysis comparing Hungary and Finland. International Marketing Review, 30(6), 510-535.

Lechner, C., \& Gudmundsson, S. V. (2014). Entrepreneurial orientation, firm strategy and small firm performance. International Small Business Journal, 32(1), 36-60.

Lee, Y.-K., Kim, S.-H., Seo, M.-K., \& Hight, S. K. (2015). Market orientation and business performance: Evidence from franchising industry. International Journal of Hospitality Management, 44, 28-37.

Leon, A. C., Davis, L. L., \& Kraemer, H. C. (2011). The role and interpretation of pilot studies in clinical research. Journal of Psychiatric Research, 45(5), 626-629.

Liu, W., Cowling, M., \& Zhang, N. (2014). The effect of enterprises' growth orientation and access to finance on small firm performance: UK evidence in an economic recession (IBSS Working Paper - Issue 3). Xi'an Jiaotong-Liverpool University. Retrieved from http://www.xjtlu.edu.cn/assets/files/research/ibss/IBSS-Working-Papers-Issue-3.pdf

Long, H. C. (2013). The relationship among learning orientation, market orientation, entrepreneurial orientation, and firm performance of Vietnam marketing communications firms. Philippine Management Review, (20), $37-46$.

Lumpkin, G. T., \& Dess, G. G. (1996). Clarifying the entrepreneurial orientation construct and linking it to performance. Academy of Management Review, 21(1), 135-172.

Lynn, M. R. (1986). Determination and qualification of content validity. Nursing Research, 35(6), 382-386.

Ma, W., Zhu, G., \& Hou, Y. (2011). Learning orientation, process innovation, and firm performance in manufacturing industry. Advances in Information Sciences and Service Sciences, 3(11), 357-364.

Martin, S. L., \& Javalgi, R. G. (2016). Entrepreneurial orientation, marketing capabilities and performance: The moderating role of competitive intensity on Latin American international new ventures. Journal of Business Research, 69(6), 2040-2051.

Martinette, L. A., \& Obenchain-Leeson, A. (2012). The relationship between learning orientation and business performance and the moderation effect of competitive advantage: A service organization perspective. Journal of Service Science, 5(1), 43-58.

Martinette, L., Obenchain-Leeson, A., Gomez, G., \& Webb, J. (2014). Relationship between learning orientation and business performance and the moderating effect of competitive advantage: An accounting services firm's perspective. International Business \& Economics Research Journal, 13(4), 779-791. 
Miller, D. (1983). The correlates of entrepreneurship in three types of firms. Management Sciences, 29(7), 770-791.

Moreira, D. F. (2016). The microeconomic impact on growth of SMEs when the access to finance widens: evidence from internet $\&$ high-tech industry. Procedia - Social and Behavioral Sciences, 220, 278-287.

Nakola, J. O., Tarus, B. K., Buigut, K., \& Kipchirchir, K. E. (2015). Effect of strategic orientation on performance of small and medium enterprises: Evidence from Kenya. International Journal of Economics, Commerce and Management, 3(11), 336-351.

Narver, J. C., \& Slater, S. F. (1990). The effect of market orientation on business profitability. Journal of Marketing, 54(4), 20-35.

Nithisathian, K., Takala, J., Rattanakomut, S., Walsh, J., Wu, Q., \& Liu, Y. (2012). Operational competitiveness development in turbulent business environment: A case study in Thailand fine gold jewelry export industry. Management and Production Engineering Review, 3(3), 53-62.

Nupap, S., Neubert, G., \& Chakpitak, N. (2012). Stakeholders' involvement in KMS implementation for Thai Ceramic SMEs: A conceptual framework. Proceedings of the 14th IFAC Symposium on Information Control Problems in Manufacturing, Romania, 1202-1207.

Nwosu, E. O., \& Orji, A. (2016). Access to formal credit and enterprise performance in Nigeria: A gender perspective. Argumenta Oeconomica, 1(36), 191-224.

Obeidat, B. Y. (2016). The effect of strategic orientation on organizational performance: The mediating role of innovation. International Journal of Communications, Network and System Sciences, 9, 478-505.

OECD. (2016). Financing SMEs and Entrepreneurs 2016: An OECD Scoreboard. Paris: The Organization for Economic Co-operation and Development (OECD).

OSMEP. (2015). White paper on small and medium enterprises of Thailand in 2015. Bangkok: Office of Small and Medium Enterprises Promotion (OSMEP).

OSMEP. (2016). White paper on small and medium enterprises of Thailand in 2016. Bangkok: Office of Small and Medium Enterprises Promotion (OSMEP).

Pathak, S., \& Ahmad, M. M. (2016). Flood recovery capacities of the manufacturing SMEs from floods: A case study in Pathumthani province, Thailand. International Journal of Disaster Risk Reduction, 18, 197-205.

Pholphirul, P., \& Bhatiasevi, V. (2012). Challenges and obstacles of small and medium enterprises under a creative economy: The case of Thailand. International Business Management, 6(3), 356-368.

Polit, D. F., \& Beck, C. T. (2006). The content validity index: are you sure you know what's being reported? critique and recommendations. Research in Nursing \& Health, 29(5), 489-497.

Polit, D. F., Beck, C. T., \& Owen, S. V. (2007). Is the CVI an acceptable indicator of content validity? Appraisal and recommendations. Research in Nursing \& Health, 30(4), 459-467.

Qu, R., \& Zhang, Z. (2015). Market orientation and business performance in MNC foreign subsidiaries-Moderating effects of integration and responsiveness. Journal of Business Research, 68(5), 919-924.

Roach, D. C. (2011). The impact of product management on SME firm performance. Journal of Research in Marketing and Entrepreneurship, 13(1), 85-104.

Rojas-Mendez, J. I., \& Rod, M. (2013). Chilean wine producer market orientation: comparing MKTOR versus MARKOR. International Journal of Wine Business Research, 25(1), 27-49.

Rojsurakitti, T. (2015). SMEs high-growth in Thailand. Advances in Social Sciences Research Journal, 3(1), 209-217.

Ruiz-Ortega, M. J., Parra-Requena, G., Rodrigo-Alarcon, J., \& Garcia-Villaverde, P. M. (2013). Environmental dynamism and entrepreneurial orientation: The moderating role of firm's capabilities. Journal of Organizational Change Management, 26(3), 475-493.

Rupeika-Apoga, R. (2014). Financing in SMEs: Case of the Baltic States. Procedia - Social and Behavioral Sciences, 150, 116-125.

Sarstedt, M., Ringle, C. M., Smith, D., Reams, R., \& Hair Jr., J. F. (2014). Partial least squares structural equation modeling (PLS-SEM): A useful tool for family business researchers. Journal of Family Business 
Strategy, 5(1), 105-115.

Sekaran, U., \& Bougie, R. (2013). Research Methods for Business: A Skill-Building Approach (6th ed.). United Kingdom: John Wiley \& Sons Ltd.

Sen, B. (2014). Multiple strategic orientations: The public library as a societal organization. Procedia - Social and Behavioral Sciences, 147, 111-119.

Shehu, A. M., \& Mahmood, R. (2014). Influence of entrepreneurial orientation and business environment on small and medium firm performance: A PLS approach. Advances in Management \& Applied Economics, 4(4), 101-114.

Sinkula, J. M., Baker, W. E., \& Noordewier, T. (1997). A framework for market-based organizational learning: Linking values, knowledge, and behavior. Journal of the Academy of Marketing Science, 25(4), 305-318.

Soininen, J. S., Puumalainen, K., Sjogren, H., Syrja, P., \& Durst, S. (2013). Entrepreneurial orientation in small firms-values-attitudes-bahevior approach. International Journal of Entrepreneurial Behavior \& Research, 19(6), 611-632.

Suliyanto, S., \& Rahab, R. (2012). The role of market orientation and learning orientation in improving innovativeness and performance of small and medium enterprises. Asian Social Science, 8(1), 134-145.

Tan, C. S. L., Smyrnios, K. X., \& Xiong, L. (2014). What drives learning orientation in fast growth SMEs?. International Journal of Entrepreneurial Behaviour \& Research, 20(4), 324-350.

Thammaruaksa, S., Saneha, W., \& Apirajkamol, S. (2010). Thai gems and jewelry industries census project. University of the Thai Chamber of Commerce Journal Humanities and Social Sciences, 30(1), 68-80.

Wolff, J. A., Pett, T. L., \& Ring, J. K. (2015). Small firm growth as a function of both learning orientation and entrepreneurial orientation: An empirical analysis. International Journal of Entrepreneurial Behavior \& Research, 21(5), 709-730.

Zebal, M. A., \& Goodwin, D. R. (2012). Market orientation and performance in private universities. Marketing Intelligence \& Planning, 30(3), 339-357.

Zhang, Y., \& Zhang, X. (2012). The effect of entrepreneurial orientation on business performance: A role of network capabilities in China. Journal of Chinese Entrepreneurship, 4(2), 132-142.

\section{Note}

Note 1. The export value of gem and jewelry products compared to Thailand's GDP in 2016, USD 406.95 billion.

\section{Copyrights}

Copyright for this article is retained by the author(s), with first publication rights granted to the journal.

This is an open-access article distributed under the terms and conditions of the Creative Commons Attribution license (http://creativecommons.org/licenses/by/4.0/). 